\title{
Reunion overseas: introduced wild boars and cultivated orange trees interact in the Brazilian Atlantic Forest
}

\author{
Josep Enric Peris ${ }^{1,2}$, Tatiane Maria Malara ${ }^{1}$, Roberta Borges ${ }^{3}$, Jose Ricardo Falconi ${ }^{4}$, \\ Leandro Peña ${ }^{1,2} \&$ Jose María Fedriani ${ }^{5,6,7 *}$
}

1. Laboratorio de Biotecnologia Vegetal. Pesquisa \& Desenvolvimento. Fundo de Defesa da Citricultura (Fundecitrus). Av. Dr. Adhemar Pereira de Barros, 201 - Vila Melhado, Araraquara, SP, Brazil; tatiane.cardamoni@fundecitrus.com.br,lpenya@fundecitrus.com.br

2. Instituto de Biología Molecular y Celular de Plantas (IBMCP). UPV-CSIC, Carrer de l'Enginyer Fausto Elio, s/n, 46011, Valencia, Spain; joperod1@bmcp.upv.es, lpenya@ibmcp.upv.es

3. Fibria Celulose S/A. Rodovia General Euriale de Jesus Zerbine, s/n, Sâo Silvestre, Jacareí, SP, Brazil; roberta.santos@fibria.com.br

4. Cambuhy Agrícola Ltda. Rodovia Washington Luiz, km. 307, Matâo, SP, Brazil; jose.falconi@cambuhy.com.br

5. Centro de Ecologia Aplicada Prof. Baeta Neves/InBIO. Instituto Superior de Agronomia. Universidade de Lisboa. Tapada da Ajuda, 1349-017, Lisboa, Portugal; fedriani@isa.ulisboa.pt

6. Estación Biológica de Doñana (CSIC). C/Américo Vespucio, 26. 41092 Isla de la Cartuja, Sevilla, Spain; fedriani@ebd.csic.es

7. Centro de Investigaciones sobre Desertificación CIDE, CSIC-UVEG-GV, Carretera de Moncada a Náquera, km 4,5. 46113 Moncada (Valencia), Spain.

* Correspondence

Received 01-X-2018. Corrected 29-V-2019. Accepted 16-VII-2019.

\begin{abstract}
Introduction: Little is known concerning novel interactions between species that typically interact in their native range but, as a consequence of human activity, are also interacting out of their original distribution under new ecological conditions. Objective: We investigate the interaction between the orange tree and wild boar, both of which share Asian origins and have been introduced to the Americas (i.e. the overseas). Methods: Specifically, we assessed whether $i$ ) wild boars consume orange (Citrus sinensis) fruits and seeds in orchards adjacent to a remnant of the Atlantic Forest of Brazil, ii) the orange seeds are viable after passing through boar's digestive tract and iii) whether the orange tree may naturalise in the forest remnant assisted by wild boars. Results: Our camera surveys indicated that wild boar was by far the most frequent consumer of orange fruits ( $40.5 \%$ of camera trap-days). A considerable proportion of sown orange seeds extracted from fresh boar feces emerged seedlings $(27.8 \%, \mathrm{~N}=386)$ under controlled greenhouse conditions. Further, $37.6 \%$ of sown seeds $(\mathrm{N}=500)$ in the forest remnant emerged seedlings in July 2015; however, after $\sim 4$ years (March 2019) only 9 seedlings survived (i.e. $4.8 \%, \mathrm{~N}=188$ ). Finally, 52 sweet orange seedlings were found during surveys within the forest remnant which is intensively used by wild boars. This study indicates a high potential of boars to act as effective seed dispersers of the sweet orange. However, harsh competition with native vegetation and the incidence of lethal diseases, which quickly kill sweet orange trees under non-agricultural conditions, could seriously limit orange tree establishment in the forest. Conclusions: Our results have important implications not only because the wild boar could be a vector of potential invasive species, but also because they disperse seeds of some native species (e.g. the queen palm, Syagrus romanzofiana) in defaunated forests, where large native seed dispersers are missing; thus, wild boars could exert critical ecological functions lost due to human activity.
\end{abstract}

Key words: agroecosystems; Citrus; frugivory; invasions; naturalization; novel interactions; seed dispersal; Sus scrofa.

Peris, J. E., Malara, T. M., Borges, R., Falconi, J. R., Peña, L., \& Fedriani, J. M. (2019). Reunion overseas: introduced wild boars and cultivated orange trees interact in the Brazilian Atlantic Forest. Revista de Biología Tropical, 67(4), 901-912. 
Novel interactions usually take place between species that interact only because of human activity and would otherwise not even coexist (Hobbs et al., 2006; Turcotte, Araki, Karp, Poveda, \& Whitehead, 2017). Thus, most typically novel interactions arise from 'introduced species' (i.e. those living outside their native distributional range due to human activity; Traveset \& Richardson, 2014; Wood et al., 2015) as well as from interactions between native and crop species (Bhagwat, Willis, Birks, \& Whittaker, 2008). Less studied are novel interactions between species that originally interact in their native range but, as consequence of human activity (domestication, hunt introductions, etc.; Parker \& Gilbert, 2004), are now interacting out of their original distribution under new ecological conditions. Here, we report one such case focused on the interaction between sweet orange trees Citrus sinensis L. Osbeck, native to Asia but cultivated worldwide, and wild boar Sus scrofa L., which is native to Eurasian and has been introduced in the Americas (i.e. the overseas) as game species. Investigating this novel interaction is important to understand the chances of naturalization of sweet oranges mediated by introduced wild boars (e.g. García, Martínez, Stouffer, \& Tylianajis, 2014).

The cultivation of citrus fruits is widespread worldwide in regions with optimal edaphoclimatic conditions for their development (30-40 ${ }^{\circ}$ North and South latitude). Although it is one of the most important fruit crops in the world, there are few studies about the basic ecology of citrus. Of particular interest is determining which animals eat their fruits and disperse their seeds. Only anecdotal evidence has been found about animals that consume cultivated citrus which has recently reviewed by Peris, Fedriani, and Peña (2015). Very little is known about whether the interactions between Citrus species and its fruit consumers (both native and introduced) are mutualistic (i.e. seed dispersal) or antagonistic (see predation; but see Gade, 1976; Ungar, 1993). For instance, we are not aware of any study that has evaluated whether Citrus seeds ingested by frugivores are viable, whether they emerge as seedlings, and how long they survive under the field conditions of non-native ranges. Such information is critical to assess the chances of Citrus species to become naturalized outside of its original range.

The wild boar has been naturalized in many countries after being introduced as a game species and due to escapes of domestic pigs with which it hybridizes (Gimenez et al., 2003). These naturalized populations are causing major environmental issues around the world (Barrios-García \& Ballari, 2012; Pedrosa, Salernob, Padilhac, \& Galetti, 2015). Wild boar adapts to a variety of habitat types and can rapidly increase its population (Massei $\&$ Genov, 2004). It is a threat to native species of flora and fauna (Bratton, 1974) and is considered one of the 100 most 'invasive species' (i.e. introduced species with a tendency to spread and to cause environmental damages; Lowe, Browne, \& Boudjelas, 2000). The boar is omnivorous, eating everything from grain to carrion, including fruit and acting as seed disperser of many large-fruited plants (e.g. Fedriani \& Delibes, 2009). Consequently, wild boar has great potential to act as an effective seed disperser (sensu Schupp, Jordano, \& Gomez, 2010) of Citrus spp. and other cultivated species, exerting thus marked ecological impacts outside of its original geographical range. Nonetheless, introduced wild boars could also act as seed dispersers of some native plant species in areas where their regular seed dispersers have been extirpated (Dirzo et al., 2014) having thus potential positive effects for some plant populations.

In this study, we evaluate the potential of introduced wild boars to act as seed dispersers of $C$. sinensis in the Atlantic Forest of Brazil. Citrus are native to the tropical and subtropical regions of Southeast Asia (Webber, 1967), with edaphoclimatic conditions similar to those of Brazilian Atlantic Forest, indicating the suitability for Citrus in our study area (A. Juliano, unpublished data). To evaluate the importance of wild boars as consumers of Citrus fruits, we made camera surveys within a large orange 
orchard adjacent to natural forest. Then, to evaluate whether boars disperse viable seeds within their feces, we conducted emergence trials with seeds extracted from boar feces under controlled greenhouse conditions. Finally, to assess orange seedlings recruitment and establishment under local field conditions we surveyed the forest remnant searching for putative orange seedlings, and also conducted seedling emergence and survival trials in the forest remnant. Specifically, we addressed the following three questions: $(i)$ Are wild boars frequent consumers of orange fruits and their seeds? (ii) Do viable orange seeds appear after passing through boar's digestive tract? (iii) Is the forest remnant an appropriate habitat for orange seedling recruitment and establishment? Based on the opportunistic feeding habits of wild boars and in their known ability to disperser large-fruited species (e.g. Fedriani \& Delibes, 2009), we hypothesized they will be effective dispersers of the sweet orange tree. However, because strong competition with native vegetation and because of the incidence of lethal diseases, which quickly kill sweet orange trees under non-agricultural conditions, we expected a low recruitment of sweet orange trees within the forest remnant.

\section{MATERIALS AND METHODS}

Study site and system: The study was carried out in Cambuhy Agrícola Ltda. (located at Matâo, Sâo Paulo, Southern Brazil; 21 ${ }^{\circ} 38^{\prime}$ S \& 48 31' W, $\sim 600$ m.a.s.l.) between April 2014 and March 2019. The agricultural farm of Cambuhy has an area of 14083 ha where sugarcane (Saccharum officinarum L.), rubber (Hevea brasiliensis (Willd. ex A., Juss.) Müll. Arg.), corn (Zea mays L.) and citrus are grown. A nature reserve of 2168 ha is found inside the farm corresponding to the Cerrado and Atlantic forest domains, called Mata da Virgínia. The predominant native vegetation is the semideciduous seasonal forest with small portions of woodland savanna, Cerrado domain (Barros, Menezes, Falconi, \& Giovanelli, 2017). The climate is warm and humid tropical with a maximum temperature of $30.1 \pm 0.37{ }^{\circ} \mathrm{C}$, a minimum temperature of $17.3 \pm 0.52^{\circ} \mathrm{C}$, and an average temperature of $22.8 \pm 0.40{ }^{\circ} \mathrm{C}$ (data obtained in the Cambuhy's weather station during 2014-2016). The annual rainfall during 2010-2016 was $1386.5+61.06 \mathrm{~mm}$, with a maximum of $1601.1 \mathrm{~mm}$ (in 2015) and a minimum of $1172.3 \mathrm{~mm}$ (in 2011).

The genus Citrus (Rutaceae) comprises perennial green trees originated in Southeast Asia. They produce hesperidium fleshy fruits divided into segments surrounded by peel that contains oil glands rich in volatile compounds. Orange is one of the most important fruit crops in the world. They are grown in more than 140 countries and, in 2015, the area planted with citrus fruits in the world was 8.7 million ha and citrus production was approximately 121 million tons (FAO statistics, 2016). An orange of the Pera cultivar matures between late May and June in Cambuhy, weighs $277.80 \pm 21.37$ $\mathrm{g}$, measures $8.2 \pm 0.12 \mathrm{~cm}$ in diameter and has a sugar pulp content of $9.67 \pm 0.13$ BRIX. The estimated production of a tree is 2000 oranges per year. Our studies were performed when the fruit was already mature but just before operational harvesting for commercial activities of the farm. Sweet orange seeds are polyembryonic, recalcitrant, non-dormant, with sizes ranging from 1.2-1.8 cm in length (Spiegel-Roy \& Goldschmidt, 1996).

Camera trap surveys of orange fruit consumers: To identify citrus frugivores and estimate their relative importance as fruit consumers, night-vision camera traps with motion sensors were installed on the trunks of orange trees and focused on mature oranges on the ground that had fallen from the tree in the cultivation plots near the forest remnant. The cameras (5 Bushnell Trophy Cam model 119446, USA and 1 Wildlife Trail model 02B, UK) were installed on cultivated trees along two rows with 3 cameras each at a distance of 6 and 76 $\mathrm{m}$ from the edge of the forest remnant, respectively. The cameras were checked daily to download the recorded images and verify their correct operation. Recording of frugivores was 
done during April-May of 2014 and 2015 in 5 consecutive days periods. Since some cameras eventually failed, overall we undertook a sampling effort of 42 camera trap-days and attained 9924 files (photos and videos) recording 679 vertebrate frugivores. Careful observations of all these files allowed us to estimate the relative importance of each recorded vertebrate as fruit consumer measured as the percentage of camera trap-days.

Occurrence viable orange seeds in boar feces and seedling emergence under controlled conditions: To estimate how often orange seeds occur in boar feces, during May 2014 we walked along three transect in the forest (two of $2000 \mathrm{~m}$ and one of $1500 \mathrm{~m}$ ) located 5-8 $\mathrm{m}$ from the orchard. Each transect was searched for mammal feces once, and we covered a width of about $10 \mathrm{~m}$ (e.g. SuárezEsteban, Delibes, \& Fedriani, 2013). At the same time, feces were sought in the first $10 \mathrm{~m}$ of the forest remnant near these citrus orchards (two transects of 1000 meters). In total, $7.5 \mathrm{~km}$ in length were covered in 2014 (Appendix).

Fresh boar feces $(\mathrm{N}=19)$ were identified (Bang \& Vivó, 1975), bagged individually, and transferred to the laboratory the same day. They were measured, fresh weighed, and then sieved by a different-sized wire mesh sieves with warm water to extract the seeds (e.g. Fedriani, Fuller, \& Sauvajot, 2001). Once cleaned, seeds were counted and stored in a refrigerator (4-6 ${ }^{\circ} \mathrm{C}$, to avoid deterioration and fungal infestation; e.g. King, Soetisma, \& Roberts, 1981) for a maximum of 7 days. Then, they were sowed under greenhouse conditions in separate pots with citrus soil (50\% Sphagnum peat, $50 \%$ coconut fiber), irrigated twice a week, $166 \mathrm{~W} /$ $\mathrm{m}^{2}$ of natural irradiation, (average temperature of $23{ }^{\circ} \mathrm{C}$, with a minimum of $18{ }^{\circ} \mathrm{C}$ and a maximum of $28^{\circ} \mathrm{C}$ ), to evaluate their viability (e.g. Fedriani, Garrote, Delgado, \& Penteriani, 2015). Together with citrus seeds, 53 seeds of queen palm (Syagrus romanzofiana) found within boar feces were sown.
Orange seedling recruitment and establishment in the forest remnant: We evaluated whether the forest remnant is an appropriate habitat for seedling recruitment and establishment by means of three approaches. Firstly, three people separated by three meters and walking in parallel straight lines through the forest remnant searched for citrus plants. During 2014, we walked two $900 \mathrm{~m}$ transects within the forest remnants (using machetes to open a path, see Appendix). During 2015, we surveyed a $3 \mathrm{~km}$ transect parallel to the line of citrus orchards but inside the forest remnant. In all cases, the width of the area surveyed along transects was $10 \mathrm{~m}$ approximately. Secondly, eight quadrants were made in the forest delimiting $60 \mathrm{~m}^{2}(6 \times 10 \mathrm{~m})$ each, taking as a reference the method proposed by Braun-Blanquet (1979). To build the quadrants, four wooden stakes nailed to the ground were used, on which threads were tied to delimit the perimeter of the study. To facilitate the work, the threads were tied every $1.5 \mathrm{~m}$ lengthwise and every $1 \mathrm{~m}$ crosswise, forming a grid. In each grid a thorough analysis of the flora resembling citrus plants was performed. Eight quadrants were made, five in 2014 and three in 2015. Finally, we experimentally assessed whether orange seeds germinate and whether seedlings survive in the forest remnant. To this end, in May 2015, sweet orange fruits were collected from four fruiting trees. Seeds were extracted and washed to remove traces of pulp and dried for 1 day at room temperature. Seeds were sown in five quadrants ( $2 \times 1 \mathrm{~m}$ each one) arranged along two lines $3 \mathrm{~km}$ apart. Whereas in the first line we set 3 quadrants at 0,15 , and $30 \mathrm{~m}$ inside the forest remnant, in the second one, due to logistic limitation, only two quadrants (at 0 and 15 $\mathrm{m}$ inside the forest) were set. As 500 seeds were required to perform this experiment, and it is extremely difficult to get those numbers from boar feces, we decided to use seeds extracted from fruits. Before seed sowing, the existing vegetation in each quadrant was removed and the soil was loosened with a hoe. The quadrants 
were subdivided into 50 grids $(20 \times 20 \mathrm{~cm})$. In each grid center, a hole of $1 \mathrm{~cm}$ in depth was made and 2 seeds were deposited, so a total of 100 seeds per quadrant were planted. Sown seeds were covered with the local soil (dried leaves were removed) and then watered every 2 weeks during the first 2 months after sowing. Thereafter, the sowings were subjected to natural conditions. Seedling emergence and growth was registered every two months.

\section{Molecular typing of citrus plants found} in the forest: A sample of three suspected Citrus seedlings found in the forest were subjected to microsatellite Simple Sequence Repeat analysis (following Pons, Navarro, Ollitrault, $\&$ Peña, 2011) to verify whether they belonged to the genus Citrus. As there was no unique marker to unequivocally distinguish among different citrus species, a multilocus analysis was made by choosing 3 different markers. These markers were CIR07C07 (Froelicher et al., 2008), CIR01C06 (Cuenca et al., 2011) and mest86 (Luro, unpublished).

\section{RESULTS}

Relative importance of orange fruit consumers: Table 1 shows the percentage of camera trap-days in which each frugivore species was recorded, the mean number $( \pm 1 \mathrm{SE})$ of different individuals recorded per day and camera, the maximum number of individuals recorded, and the functional group of visitors (seed dispersers, seed predators, and pulp consumers). Among citrus seed dispersers, nonnative wild boars were the most frequently recorded (40.5\%; Fig. 1), followed by Azara agouti $(21.4 \%)$ and Lowland agouti $(16.7 \%$; Table 1), being these differences significant $\left(\chi^{2}\right.$ $=6.90$, d.f. $=2, \mathrm{P}<0.05)$. Further, we detected up to 6 wild boars per day and per camera, while only up to 2 agoutis (Table 1). Thus, we considering the number of recorded individuals of each disperser species the predominance of wild boars as seed dispersers $(58.9 \%)$ when compared to Azara agouti (25.0 \%) and Lowland agouti $(16.1 \%)$ was larger $\left(\chi^{2}=25.8\right.$, d.f. $=2, \mathrm{P}<0.0001)$. The most abundant pulp

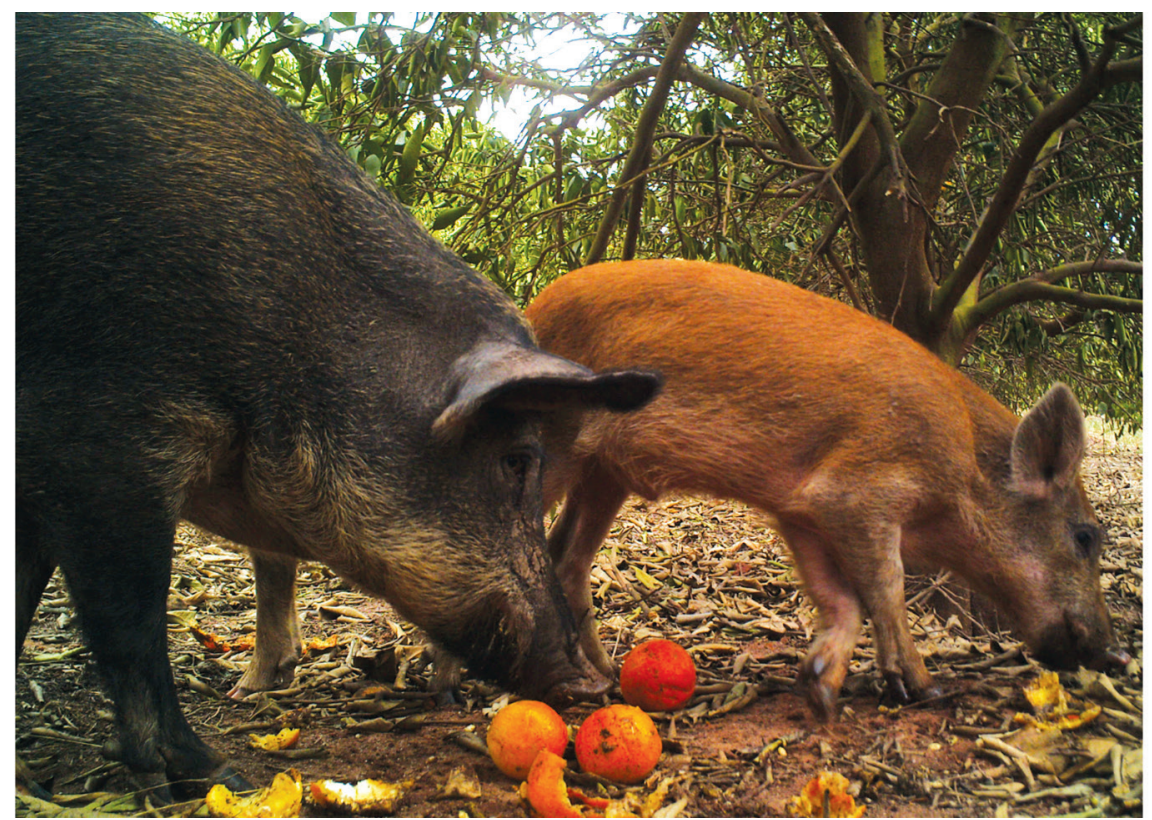

Fig. 1. Wild boars (Sus scrofa L.) eating mature sweet orange fruits under the canopy of a tree in an orchard near the forest remnant. Because the species often hybridizes with domestic pigs, the possibility exists that the photographed individuals are hybrids. 
consumers were unidentified small birds (that were recorded almost every camera trap-day) and that were often recorded consuming pulp and vesicle remains scattered by wild boars. Seed predators (small rodents, capybara, and tapeti) were infrequent visitors (Table 1).

The mean number of animals observed per day and per camera, the maximum number of animals recorded and the functional guild of each frugivore. Our sampling effort (42 camera trap-days) rendered 9924 files (photos and videos) of 679 different vertebrate frugivores.

Wild boar dispersal of viable orange seeds: Most boar feces $(68.4 \%, \mathrm{~N}=19)$ contained citrus seeds. The mean number of citrus seeds per boar feces was $29.1 \pm 7.9$, ranging from 4-101 (overall, 386 seeds in 14 feces). Citrus seedlings started to emerge one week after planting. Emergence percentage of citrus seedlings three months after sowing was 27.8 $\%$ (Table 2). No seedling emerged later than 3 months after planting. In addition to citrus seeds, two out of 53 seeds of queen palm found within boar feces emerged seedlings within the first 2 months after sowing (Table 2).

Orange seedling emergence and establishment in the forest remnant: No citrus seedlings were found in the three transects searched in 2014. However, 48 citrus seedlings were found within the $3-\mathrm{km}$ transects searched in 2015 (they were grouped into 5 clusters within $50 \mathrm{~m}^{2}$ ). The mean height of these seedlings (including roots) was $10.60 \pm 1.53 \mathrm{~cm}$, ranging from $5-40 \mathrm{~cm}$. Their estimated age was between 6 months and 2 years. In addition, we found four seedlings in one (out of 8) $60 \mathrm{~m}^{2}$ established quadrants. All 52 seedlings were taken to the laboratory, measured, and analysed to confirm their genetic identity.

Three of the presumed citrus seedlings found in the forest remnant were verified as citrus types based on molecular markers. Citrus seedlings were identified as sweet oranges according to their SSR profiles, clearly distinguishable for those of mandarin (Citrus reshni Hort. ex Tan.) and clementine (Citrus

TABLE 1

Percentage of animal observations in Cambuhy (Brazil) through the use of camera-traps

\begin{tabular}{lcccll}
\multicolumn{1}{c}{ Species } & $\begin{array}{c}\text { \% of days } \\
\text { filmed }\end{array}$ & Mean \pm S.E. & Maximum & $\begin{array}{c}\text { Functional } \\
\text { group }\end{array}$ & \multicolumn{1}{c}{ Reference } \\
Sus scrofa & 40.5 & $1.94 \pm 2.5$ & 6 & Seed disperser & Barrios-García \& Ballarri, 2012 \\
Dasyprocta azarae & 21.4 & $1.55 \pm 0.2$ & 2 & Seed disperser & Ribeiro and Vieira, 2014 \\
Cuniculus paca & 16.7 & $1.28 \pm 0.3$ & 2 & Seed disperser & Wenny, 2000 \\
Nasua nasua & 7.1 & $1 \pm 0.0$ & 1 & Seed disperser & Alves-Costa and Eterovick, 2007 \\
Cerdocyon thous & 4.8 & $1 \pm 0.0$ & 1 & Seed disperser & Rocha et al., 2004 \\
Small birds & 97.6 & $11.63 \pm 11.6$ & 50 & Pulp feeders & Personal observation \\
Turdus leucomelas & 76.2 & $1.71 \pm 1.8$ & 4 & Pulp feeders & Personal observation \\
Columbina talpacoti & 59.5 & $1.84 \pm 2.2$ & 4 & Pulp feeders & Personal observation \\
Aramides cajaneus & 28.6 & $1.91 \pm 0.1$ & 3 & Pulp feeders & Personal observation \\
Hydrochoerus hydrochaeris & 2.4 & $10 \pm 0.0$ & 10 & Seed predator & Personal observation \\
Sylvilagus brasiliensis & 4.8 & $1 \pm 0.0$ & 1 & Seed predator & Personal observation \\
Small rodents & 4.8 & $1 \pm 0.0$ & 1 & Seed predator & Personal observation \\
Dasypus novemcinctus & 2.4 & $1 \pm 0.0$ & 1 & Unknown & \\
Iguana spp. & 2.4 & $1 \pm 0.0$ & 1 & Unknown & \\
Penelope spp. & 2.4 & $1 \pm 0.0$ & 1 & Unknown & \\
\hline
\end{tabular}


TABLE 2

Fresh weight and number of seeds (Citrus sp., Syagrus romanzofiana, Zea mays and unidentified species) found in wild boar feces collected at the grove-forest remnant ecotone. The emergence percentage of citrus seedlings under greenhouse conditions is also shown

\begin{tabular}{|c|c|c|c|c|c|c|c|}
\hline \multirow{2}{*}{ Sample } & \multirow{2}{*}{$\begin{array}{c}\text { Fresh } \\
\text { weight }(\mathrm{g})\end{array}$} & \multicolumn{4}{|c|}{ Number of seeds and plant species found } & \multicolumn{2}{|c|}{ Citrus seedling emergence } \\
\hline & & Citrus sp. & Syagrus romanzofiana & Zea mays & Non-identified & Total & $\%$ \\
\hline 1 & 62.1 & 79 & & & & 8 & 10.1 \\
\hline 2 & 78.2 & 101 & 2 & & & 17 & 16.8 \\
\hline 3 & 69.3 & 43 & & & & 12 & 27.9 \\
\hline 4 & 69.4 & 32 & & & & 14 & 43.8 \\
\hline 5 & 50.3 & 9 & & & 9 & 7 & 77.8 \\
\hline 6 & 23.5 & 4 & 2 & & & 0 & 0 \\
\hline 7 & 103.7 & 4 & 15 & & & 0 & 0 \\
\hline 8 & 124.1 & - & 3 & & & - & - \\
\hline 9 & 109.3 & 28 & & & & 15 & 53.6 \\
\hline 10 & 133.2 & - & & & & - & - \\
\hline 11 & 63.5 & - & & 1 & & - & - \\
\hline 12 & 33.8 & 9 & & & & 0 & 0 \\
\hline 13 & 152.6 & 38 & 1 & 12 & & 15 & 39.5 \\
\hline 14 & 45.9 & 3 & & & & 0 & 0 \\
\hline 15 & 98.6 & 19 & & & & 17 & 89.5 \\
\hline 16 & 38.3 & 9 & & & & 0 & 0 \\
\hline 17 & 99.1 & - & 22 & & & - & - \\
\hline 18 & 33.4 & 8 & & & & 0 & 0 \\
\hline 19 & 180.4 & - & 53 & & & - & - \\
\hline
\end{tabular}

clementina Hort. ex Tan.) controls. This result is expected as citrus orchards at Cambuhy consisted basically of sweet orange trees.

\section{Sweet orange sowing in the forest rem-} nant: Two months after sowing seeds in the forest remnant (i.e. July 2015), $37.6 \%$ of sown seeds $(\mathrm{N}=500)$ emerged seedlings. Seedling survival rates decreased over the following years, being $72.3 \%(\mathrm{~N}=188)$ one year later (July 2016), $46.8 \%(\mathrm{~N}=188)$ two years later (March 2017) and 26.6\% after three years (May 2018) and $4.8 \%$ after four years (March 2019). In May 2018, wild boars completely destroyed two quadrants. In March 2019, the 9 surviving orange seedlings were from 9 to $42 \mathrm{~cm}$ long, with an average height of $27.72 \pm 3.41 \mathrm{~cm}$.

\section{DISCUSSION}

Peris et al. (2015) recently reviewed citrus fruit vertebrate consumers and reported up to 28 vertebrate species. Other authors have detailed citrus fruit consumption by wild mammals and birds, as well as by livestock, both in areas where it is cultivated (e.g. Argentina, Dominica, Tanzania and Pakistan (Din \& Ghazanfar, 1980; Shafi, Khan, \& Hussain, 1986; Navarro, Martella, \& Chediack, 1991; Wiley, 1993; Corp \& Byrne, 2004; Stampella, Delucchi, Keller, \& Hurrell, 2014) and where it is native (e.g. Torii, 1986; Ungar, 1993; Kitamura et al., 2002). Surprisingly, however, none of these studies have evaluated whether citrus frugivores acted as seed dispersers or as predators. To our knowledge, this is the first study evaluating the qualitative seed dispersal 
effectiveness (Schupp et al., 2010) of Citrus species, either in its native range or in areas where the species is cultivated. Based on our camera survey (Table 1) and field observations (e.g. fruit remains found underneath trees), wild boar was the only frequent species (40.5 $\%)$ that visited fruiting orange trees, consumed whole fruits, and that could act as an effective seed disperser (Fig. 1). Other mammals that could act as seed dispersers (e.g. Azara agouti, Lowland agouti, crab-eating fox) were much less frequent (5-21 \%; Table 1). For example, Zuracatto, Carrara, \& Franco (2010) documented Lowland agouti eating citrus fruits (including their seeds) in the Atlantic Forest of Brazil. For example Jansen et al. (2010) indicates that Central American agouti (Dasyprocta punctata) is of great ecological importance as seed predators and seed dispersers. Zuracatto et al. (2010) found that Lowland agouti consume both the endocarp and the seeds of $C$. sinensis, Citrus limon and Citrus deliciosa. However, Smythe (1978) indicate that agoutis (Dasyprocta spp.) eat, but do not disperse, seeds of certain Citrus species. In our study, we also very frequently recorded several bird species underneath orange trees; however, they were always picking pulp remains from fruits previously processed by boars or from fungusinfected fruits (which soften the fruit peel allowing birds to access the pulp; Peris, Rodríguez, Peña, \& Fedriani, 2017) and no evidence of seed ingestion (and thus potential dispersal) was found during this study. Thus, the potential role of other mammals on citrus seed dispersal deserves further research.

The emergence experiments in the greenhouse and in the forest remnant, as well as our field surveys, where we found several citrus seedlings within the forest remnant, strongly support the conclusion that wild boars are acting as relatively effective dispersers of $C$. sinensis seeds. Surprisingly, however, we have not found any adult orange trees in the forest despite intensive searches, which could be explained in at least two ways. Firstly, since $C$. sinensis has a long period of juvenility, ranging from 7 to more than 10 years (Spiegel-Roy
\& Goldschmidt, 1996), it could be due to a lack of time to recruit into adult trees. However, this seems unlikely since the orange tree orchards in Cambuhy Agrícola Ltda. were established in the 1970's. Secondly, although sweet orange seeds reach the forest, germinate, and seedlings emerge, perhaps they might not find the appropriate conditions to establish as adult individuals. Although the soil and climate conditions were optimal for the emergence and growth of citrus trees, competition with the abundant wild plants for water, light and nutrients could prevent citrus establishment. In addition, there are certain lethal and ubiquitous diseases for sweet orange trees such as Tristeza (caused by Citrus tristeza virus) or gummosis (caused by Phytophthora spp.) which quickly kill sweet orange trees under non-agricultural conditions (Spiegel-Roy \& Goldschmidt, 1996; Moreno, Ambrós, Albiach-Martí, Guerri, \& Peña, 2008). Indeed, most cases of citrus and Rutaceae naturalization have been reported in areas near their centers of origin and diversity, such as China and Southeast Asia (see Hong \& Blackmore, 2015). In the Americas, as a result of their introduction for cultivation as a combination of rootstocks and scions of two different genotypes, only rootstock types have been found naturalized (Gade, 1979; Nesom, 2014). Therefore, it seems that the sweet orange has never been found naturalized in South America, which may explain the lack of success in our attempts either to find or to establish sweet orange adult in the forest remnants.

The wild boar is becoming a major matter of concern for the conservation of biodiversity in many areas around the world (Massei \& Genov 2004; Barrios-García \& Ballari, 2012; Pedrosa et al., 2015). In spite of its increasing distribution and density, there is a lack of information about their interactions with other species in the new distribution. Specifically, wild boars are becoming widespread and ubiquitous in several areas previously occupied by Atlantic forests of Brazil (Pedrosa et al., 2015). Here we show that they act as effective seed dispersers of the sweet orange tree in Southern Brazil, which could be environmental issue if this 
exotic plant establish and become invasive. On the other hand, boars also acted as seed dispersers of the native queen palm. This finding could be especially relevant in defaunated areas of the Brazilian Atlantic forest (Chiarello, 1999; Galetti et al. 2017) where wild boars, through their novel interactions with native plants, could provide them with lost seed dispersal services. Boars could be dispersing many cultivated Citrus species in different areas of the world where both species have been introduced and favoured by human influences through citrus orchard abandonment, farming or lumbering practices (Gade, 1976). Thus, further studies concerning the pervasiveness and potential ecological outcomes of such novel interactions in other areas are clearly needed.

Ethical statement: authors declare that they all agree with this publication and made significant contributions; that there is no conflict of interest of any kind; and that we followed all pertinent ethical and legal procedures and requirements. All financial sources are fully and clearly stated in the acknowledgements section. A signed document has been filed in the journal archives.

\section{ACKNOWLEDGMENTS}

We sincerely thank A. Tachibana for allowing us to work at Fazenda Cambuhy Agrícola and to his staff for helping to perform our field experiments. We thank Fundecitrus for funding and technical support. Eugene Schupp and three anonymous reviewers provided numerous comments and suggestions which greatly improved an earlier draft. JMF was funded by a Portuguese FCT grant (IF/00728/2013).

\section{RESUMEN}

Reunión en el extranjero: los jabalíes introducidos y los naranjos cultivados interactúan en el bosque atlántico brasileño. Introducción: Se conoce relativamente poco sobre las llamadas 'interacciones noveles' entre especies que típicamente interactúan en su área de distribución nativa pero que, como consecuencia de la actividad humana, también interactúan fuera de su distribución original bajo nuevas condiciones ecológicas. Objetivo: Investigamos la interacción entre el naranjo y el jabalí, ambos con origen asiático e introducidos en las Américas (es decir, del extranjero). Métodos: Específicamente, evaluamos si $i$ ) los jabalíes consumen frutas y semillas del naranjo (Citrus sinensis) en naranjales adyacentes a un parche remanente del bosque atlántico de Brasil, ii) las semillas de naranja son viables tras pasar por el tracto digestivo del jabalí, y iii) si el naranjo puede llegar a naturalizarse en el parche de bosque gracias a los jabalíes. Resultados: Los resultados de nuestro fototrampeo indicaron que el jabalí fue, con mucho, el consumidor más frecuente de las naranjas (40.5\% cámaras trampa-días). Una proporción considerable de semillas de naranjo extraídas de heces de jabalí frescas y sembradas emergieron plántulas bajo condiciones de invernadero controladas $(27.8 \%, \mathrm{~N}=386)$. Además, del $37.6 \%$ de las semillas sembradas $(\mathrm{N}=500)$ en el parche remanente de bosque emergieron plántulas en julio 2015; sin embargo, después de $\sim 4$ años (marzo 2019) solo sobrevivieron 9 plántulas (es decir, $4.8 \%, \mathrm{~N}=188$ ). Finalmente, se encontraron 52 plántulas de naranja dulce durante varias prospecciones dentro del parche de bosque que es utilizado intensivamente por los jabalíes. Este estudio indica un alto potencial de los jabalíes para actuar como dispersores de semillas eficaces del naranjo dulce. Sin embargo, la severa competencia con la abundante vegetación nativa y la incidencia de enfermedades letales, que matan rápidamente los naranjos dulces en condiciones no agrícolas, podrían limitar seriamente el establecimiento de naranjos en el bosque. Conclusiones: Nuestros resultados tienen implicaciones importantes no solo porque el jabalí podría ser un vector de posibles especies de plantas invasoras, sino también porque dispersan semillas de algunas especies nativas (p.e., la palmera reina, Syagrus romanzofiana) en estos bosques defaunados, donde faltan dispersores nativos de semillas de gran tamaño. Por ello, los jabalíes podrían ejercer funciones ecológicas críticas que se han perdido debido a la actividad humana.

Palabras clave: agroecosistemas; Citrus; frugivoría; invasiones; naturalización; interacciones noveles; dispersión de semillas; Sus scrofa.

\section{REFERENCES}

Alves-Costa, C. P., \& Eterovick, P. C. (2007). Seed dispersal services by coatis (Nasua nasua, Procyonidae) and their redundancy with other frugivores in southeastern Brazil. Acta Oecologica, 32, 77-92.

Bang, P., \& Vivó, J. (1975). Huellas y señales de los animales de Europa. Barcelona: Omega.

Barrios-García, M. N., \& Ballari, S. A. (2012). Impact of wild boar (Sus scrofa) in its introduced and native range. A review. Biological Invasions, 14, 2283-2300. 
Barros, A. B., Menezes, F. A., Falconi, J. R., \& Giovanelli, J. G. (2017). Fauna de répteis dos remanescentes florestais e cultivos agrícolas da Fazenda Cambuhy, municípios de Matâo, Nova Europa e Tabatinga, regiâo Noroeste do estado de Sâo Paulo. Biotemas, 30, 79-90.

Bhagwat, S. A., Willis, K. J., Birks, H. J. B., \& Whittaker, R. J. (2008). Agroforestry: a refuge for tropical biodiversity? Trends in Ecology \& Evolution, 23, 261-267.

Bratton, S. P. (1974). The effect of the European wild boar (Sus scrofa) on the high elevation vernal flora in Great Smoky Mountains National Park. Bulletin of the Torrey Botanical Club, 101, 198-206.

Braun-Blanquet, J. (1979). Fitosociología. Base para el estudio de las comunidades vegetales. Madrid: Blume.

Chiarello, A. G. (1999). Effects of fragmentation of the Atlantic forest on mammal communities in southeastern Brazil. Biological Conservation, 89, 71-82.

Corp, N., \& Byrne, R. W. (2004). Sex difference in chimpanzee handedness. American Journal of Physical Anthropology, 123, 62-68.

Cuenca, J., Froelicher, Y., Aleza, P., Juárez, J., Navarro, L., \& Ollitrault, P. (2011). Multilocus half tetrad analysis and centromere mapping in citrus; evidences of SDR mechanism for $2 \mathrm{n}$ mega gametophyte production and partial chromosome interference in mandarin $\mathrm{cv}$ fortune. Heredity, 107, 462-470.

Din, H. U., \& Ghazanfar, S. A. (1980). Flora of Pakistan. No. 132. Rutaceae. Karachi: University of Karachi.

Dirzo, R., Young, H. S., Galetti, M., Ceballos, G., Isaac, N. J., \& Collen, B. (2014). Defaunation in the Anthropocene. Science, 345, 401-406.

FAO. (2016). Citrus Fruit Statistics. Retrieved from www. faostat.fao.org

Fedriani, J. M., \& Delibes, M. (2009). Seed dispersal in the Iberian pear Pyrus bourgaeana: a role for infrequent mutualists. Ecoscience, 16, 311-321.

Fedriani, J. M., Fuller, T. K., \& Sauvajot, R. M. (2001). Does availability of anthropogenic food enhance densities of omnivorous mammals? An example with coyotes in southern California. Ecography, 24, 325-331.

Fedriani, J. M., Garrote, P. J., del Mar Delgado, M., \& Penteriani, V. (2015). Subtle gardeners: inland predators enrich local topsoils and enhance plant growth. PloS one, 10(9), e0138273.

Froelicher, Y., Dambier, D., Bassene, J. B., Costantino, G., Lotfy, S., Didout, C., Beamont, V., Brottlier, P., Risterucci, A. M., Luto, F., \& Ollitrault, P. (2008). Characterization of microsatellite markers in mandarin orange (Citrus reticulata Blanco). Molecular Ecology Resources, 8, 119-122.

Gade, D. W. (1976). Naturalization of plants aliens: the volunteer Orange in Paraguay. Journal of Biogeography, 3, 269-279.

Gade, D. W. (1979). Petitgrain from Citrus aurantium: essential oil of Paraguay. Economic Botany, 3, 63-71.

Galetti, M., Brocardo, C. R., Begotti, R. A., Hortenci, L., Rocha-Mendes, F., Bernardo, C. S. S., Bueno, R. S., Nobre, R., Bovendorp, R. S., Meirelles, F., Gobbo, S. K., Beca, G., \& Schmaedecke, G. (2017). Defaunation and biomass collapse of mammals in the largest Atlantic forest remnant. Animal Conservation, 20, 270-281.

García, D., Martínez, D., Stouffer, D. B., \& Tylianakis, J. M. (2014). Exotic birds increase generalization and compensate for native bird decline in plantfrugivore assemblages. Journal of Animal Ecology, $83,1441-1450$.

Gimenez, D. L., da Mota, L. S., Curi, R. A., Rosa, G. J., Gimenes, M. A., Lopes, C. R., \& Lucca, E. J. (2003). Cytogenetic and molecular analysis of a European wild boar Sus scrofa scrofa and domestic swine Sus scrofa domesticus. Brazilian Journal of Veterinary Research and Animal Science, 40, 146-154.

Hobbs, R. J., Arico, S., Aronson, J., Baron, J. S., Bridgewater, P., Cramer, V. A., Epstein, P. R., Ewel, J. J., Klink, C. A., Lugo, A. E., Norton, D., Ojima, D., Richardson, D. M., Sanderson, E. W., Valladares, F., Vilà, M., Zamora, R., \& Zobel, M. (2006). Novel ecosystems: theoretical and management aspects of the new ecological world order. Global Ecology \& Biogeography, 15, 1-7.

Hong, D., \& Blackmore, S. (2015). The plants of China. Cambridge: Cambridge University Press.

Jansen, P. A., Elschot, K., Verkerk, P., J., \& Wright, J. (2010). Seed predation and defleshing in the agoutidispersed palm Astrocaryum standleyanum. Journal of Tropical Ecology, 26, 473-480.

King, M. W., Soetisna, U., \& Roberts, E. H. (1981). The dry storage of citrus seeds. Annals of Botany, 48, 865-872.

Kitamura, S., Yumoto, T., Poonswad, P., Chuailua, P., Plongmai, K., Maruhashi, T., \& Noma, N. (2002). Interactions between fleshy fruits and frugivores in a tropical seasonal forest in Thailand. Oecologia, 133, 559-572.

Lowe, S. M., Browne, B., \& Boudjelas, S. (2000). 100 of the World's Worsy Invasive Alien Species. Auckland: Invasive Species Specialist Group. IUCN.

Massei, G., \& Genov, P. V. (2004). The environmental impact of wild boar. Galemys, 16, 135-145. 
Moreno, P., Ambrós, S., Albiach-Martí, M. R., Guerri, J., \& Peña, L. (2008). Plant diseases that changed the world, Citrus tristeza virus: A pathogen that changed the course of the citrus industry. Molecular Plant Pathology, 9, 251-268.

Navarro, J. L., Martella, M. B., \& Chediack, A. (1991) Analysis of Blue-fronted Amazon damage to a citrus orchard in Tucumán, Argentina. Agriscientia, 8, 75-78.

Nesom, G. L. (2014). Citrus trifoliata (Rutaceae): Review of biology and distribution in the USA. Phytoneuron, $46,1-14$.

Parker, I. M., \& Gilbert, G. S. (2004). The evolutionary ecology of novel plantpathogen interactions. Annual Review of Ecology and Systematics, 35, 675-700.

Pedrosa, F., Salernob, R., Padilhac, F. V. B., \& Galetti, M. (2015). Current distribution of invasive feral pigs in Brazil: economic impacts and ecological uncertainty. Natureza \& Conservação, 13, 84-87.

Peris, J. E., Fedriani, J. M., \& Peña, L. (2015). Los mamíferos frugívoros prefieren frutos de cítricos infectados por Penicillium digitatum: ¿se equivocaba Janzen? Ecosistemas, 24, 5-13.

Peris, J. E., Rodríguez, A., Peña, L., \& Fedriani, J. M. (2017). Fungal infestation boosts aroma and fruit removal by mammals and birds. Scientific Reports, 7, 1-9.

Pons, E., Navarro, A., Ollitrault, P., \& Peña, L. (2011). Pollen Competition as a Reproductive Isolation Barrier Represses Transgene Flow between Compatible and Co-Flowering Citrus Genotypes. PLoS ONE, 6, e25810.

Ribeiro, J. F., \& Vieira, E. M. (2014). Interactions between a seed-eating neotropical rodent, the Azara's agouti (Dasyprocta azarae), and the Brazilian 'pine' Araucaria angustifolia. Austral Ecology, 39, 279-287.

Rocha, V. J., Reis, N. R., \& Sekiama, M. L. (2004). Dieta e dispersâo de sementes por Cerdocyon thous (Linnaeus) (Carnívora, Canidae) em un fragmento florestal no Paraná, Brasil. Revista Brasileira de Zoologia, 21,871-876.

Schupp, E. W., Jordano, P., \& Gomez, J. M.. (2010). Seed dispersal effectiveness revisited: a conceptual review. New Phytologist, 188, 333-353.

Shafi, M. M., Khan, A. A., \& Hussain, I. (1986). Parakoet, Psittacula krameri (Scopoli), damage in citrus fruits in Punjab, Pakistan. Bombay Natural History Society, $83,438-444$.
Smythe, N. (1978). The natural history of the Central American agouti (Dasyprocta punctata). Smithsonian Contribution to Zoology, 257, 1-52.

Spiegel-Roy, P., \& Goldschmidt, E. E. (1996). The Biology of Citrus. Cambridge: Cambridge University Press.

Stampella, P. C., Delucchi, G., Keller, H. A., \& Hurrell, J. A. (2014). Etnobotánica de Citrus reticulate (Rutaceae, Aurantioideae) naturalizada en la Argentina. Bonplandia, 23, 151-162.

Suárez-Esteban, A., Delibes, M., \& Fedriani, J. M. (2013). Barriers or corridors? The overlooked role of unpaved roads in endozoochorous seed dispersal. Journal of Applied Ecology, 50, 767-774.

Torii, H. (1986). Food habits of the Masked Palm Civet, Paguma larvata Hamilton-Smith. Journal of the Mammalogical Society of Japan, 11, 39-43.

Traveset, A., \& Richardson, D. M. (2014). Mutualistic interactions and biological invasions. Annual Review of Ecology, Evolution, and Systematics, 45, 89-113.

Turcotte, M. M., Araki, H., Karp, D. S., Poveda, K., \& Whitehead, S. R. (2017). The eco-evolutionary impacts of domestication and agricultural practices on wild species. Philosophical Transactions of the Royal Society, 372, 20160033.

Ungar, P. S. (1993). Fruit preferences of four sympatric primate species at Ketambe, Northern Sumatra, Indonesi. International Journal of Primatology, 16, 221-245.

Webber, H. J. (1967). History and development of the citrus industry. In W. Reuther, H. B. Webber, \& L. D. Batchelor (Eds.), The citrus industry (pp. 1-37). Berkeley: University of California Press.

Wenny, D.G. (2000). Seed dispersal, seed predation, and seedling recruitment of a Neotropical Montane Tree. Ecological Monographs, 70, 331-351.

Wiley, J. W. (1993). Citrus crop damage by parrots in Dominica (Report). Grambling: Grambling State University.

Wood, J. R., Dickie, I. A., Moeller, H. V., Peltzer, D. A., Bonner, K. I., Rattray, G., \& Wilmshurst, J. M. (2015). Novel interactions between non-native mammals and fungi facilitate establishment of invasive pines. Journal of Ecology, 103, 121-129.

Zuracatto, R., Carrara, R., \& Franco, B. K. S. (2010). Dieta da paca (Cuniculus paca) usando métodos indiretos numa área de cultura agrícola na Floresta Atlântica brasileira. Biosistemas, 23, 235-239. 


\section{APPENDIX}

Perimeter of the Cambuhy Farm, location of the citrus orchards, and details of the four transects made. The greenhouse is located in the farm, about 0.5-2 kilometers from transects.
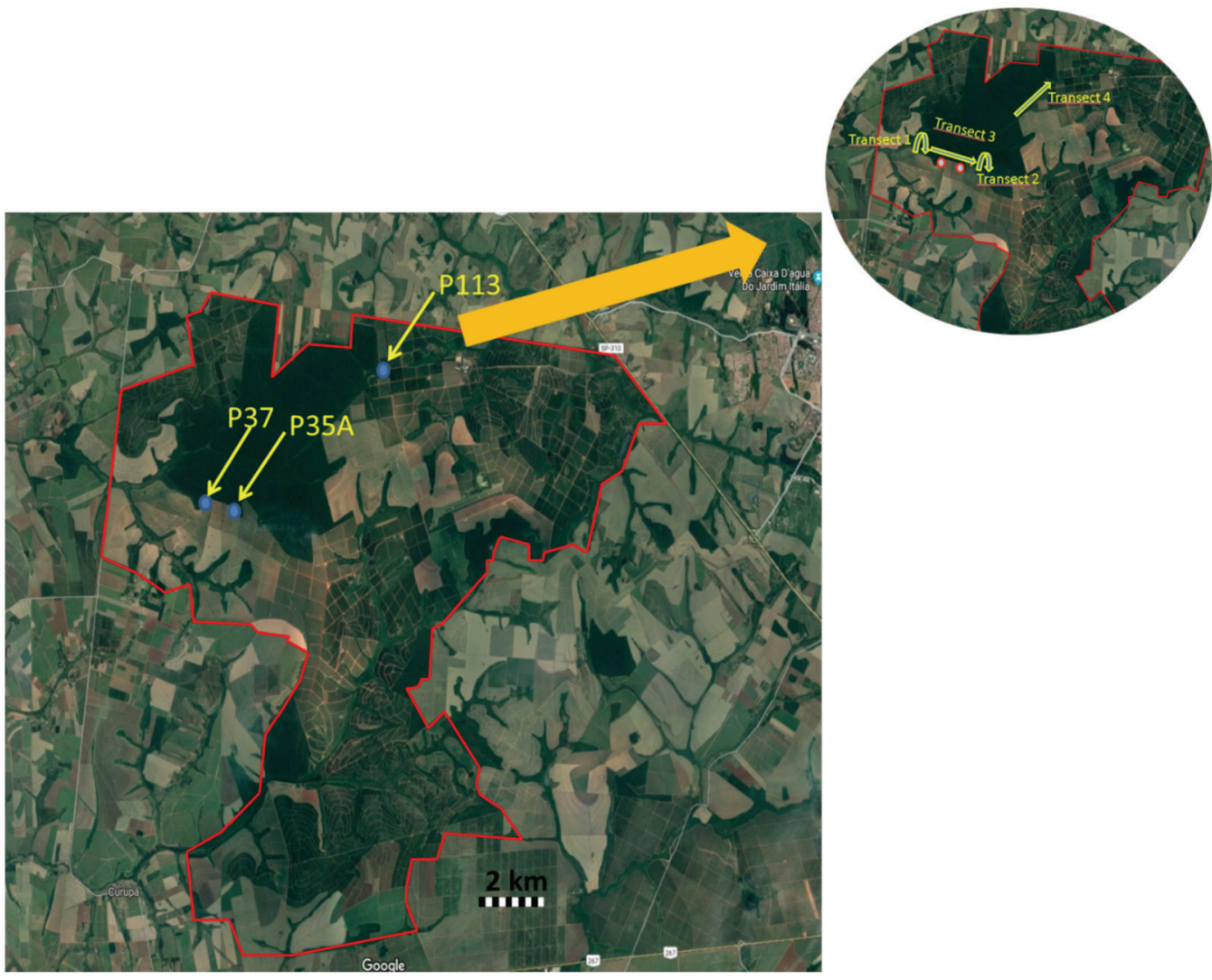